DOI https://doi.org/10.32405/2218-7650-2021-16(45)-93-109

UDC: 373.1.02; 374

Jabbarova Konul Hidayat,

Lecturer of the Mingachevir State University,

PhD student of Institute of Education of the Republic of Azerbaijan.

Mingachevir, Azerbaijan.

ORCID iD: https://orcid.org/0000-0003-2137-2412

kenulcabbarova@gmail.com

\title{
OPPORTUNITIES OF THE PEDAGOGICAL QUARTET IN THE PREVENTION OF DEVIANT BEHAVIOR, TAKING INTO ACCOUNT THE PEDAGOGICAL AND PSYCHOLOGICAL CHARACTERISTICS OF SENIOR STUDENTS
}

\begin{abstract}
The emergence of socio-pedagogical factors of deviant behavior among high school students depends on the level of family, school and social education. The moral upbringing of high school-age children is based on the family, so the irresponsible attitude to their fate, the presence of double morals in their upbringing and the parents' use of alcohol and drugs lead to disharmony in the family, resulting in immoral behavior and these make to take the first step on the way of deviant behavior. Although a high school student wants to adapt to the demands of society, he cannot do so because he cannot define his social role properly and does not know the ways of social adaptation. The article analyzes the ways of organizing joint work of the family, school and community on the prevention of deviant behavior among senior students, and presents a theoretical model of pedagogical prevention of deviant behavior of senior students, directions of preventive work. School, family, work collectives and society are presented as sides of the pedagogical quartet. Features, methods of work, etc. in each direction indicated in the model are analyzed. The main goal of society and the school education system in modern times is to ensure the civil participation of adolescents, especially high school students, in the life of a changing society. However, the lack of real programs, specially trained teachers on deviant behavior and a poorly developed network of methodological support lead to a delay in this process. The article makes some suggestions on these issues as well. As a result of the analysis, it is concluded that the prevention of deviant behavior of adolescents requires the development and implementation of special preventive measures. It also provides a basis for the implementation of a system of preventive measures at the legal, social,
\end{abstract}


medical, psychological and pedagogical levels.

Keywords: high school student; supervision; family; school; deviant behavior; social environment; pedagogical prevention.

\section{INTRODUCTION / ВСТУП / ВВЕДЕНИЕ}

Formulation of the problem. The economic, social and cultural changes took place in the late 20 th and early 21 st centuries literally could not provide a comprehensive development of the growing young. As a result, an increase in the deviant behavioral patterns among schoolchildren and upper class students are clearly observed. The most dangerous types of deviant behavior are criminal cases, and the scale of criminalization among teenagers and young people. According to UNICEF, per year, about $2-3 \%$ of the crimes are committed by teenagers [1]. In 2016, deviations such as Internet addiction, gambling, and so on improved existence of non-standard behavioral situations. However, the problem of preventing deviant behavior in most countries has started to be of primary importance.

Solution issues of the problems have reached the state-level and the prophylaxis of deviant behavior of teenagers and children has turned into a major social-pedagogical problem of the modern era.

Nowadays, researchers have discovered that, for some reasons, deviant behavior among young people is more common in comparison with other age groups. One of the main reasons is the physiological characteristic of the body that is behind the social development and the formation.

Analysis of the latest relevant research and publications. This research is based on the sources written by various authors such as «Features of the leading activity of adolescent children» by D. Feldstein [4], «Personality and its formation in childhood» by L. Bozhovich [2], «Methods of Preventing Deviant Behavior among Adolescents in Secondary School» by I. Kandugasheva [6], «Family pedagogy» by R. Huseynzadeh [9], «Engaging Troubling Students» by S. Danforth [7], «Pedagogical prevention of game addictions in adolescents in a general education institution» by M. Bredikhina [10], «Personality and its development in childhood» by L. Bozhovich [5], «Teacher's pedagogical skills» by M. İlyasov [11], «Drug addiction: prevention program for adolescents and young people» by N. Sirota [12], «Social pedagogy» by H. Alizade [14], etc.

An analysis of the relevant scientific literature shows that the issue of pedagogical prevention of deviant behavior of high school students has been studied in more detail by Y. Zmanovskaya, Y. Kleyberg, Y. Sayenko, M. Lvova, S. Quliyeva, Y. Gilinski and others. 


\section{AIM AND TASKS / МЕТА ТА ЗАВДАННЯ / ЦЕЛИ И ЗАДАЧИ}

The aim of the study is to analyze ways to organize the joint activities of the family, school and community in the pedagogical prevention of deviant behavior of high school students.

For this purpose, the article sets the following tasks:

- to review pedagogical-psychological characteristics in the prevention of deviant behavior of senior students;

- to show the role of school, family and community cooperation in the field of prevention of deviant behavior of high school students.

THE THEORETICAL BACKGROUNDS / TEOPETИЧHI ОСНОВИ ДОСЛІДЖЕННЯ / ТЕОРЕТИЧЕСКИЕ ОСНОВЫ ИССЛЕДОВАНИЯ

The theoretical basis of the study was:

- modern provisions of the theory and practice of preventive education (Y. Gilinsky, S. Zavrazhin, Y. Zmanovskaya, Y. Kleyberg);

- research on preventive pedagogy (N. Lapshin, B. Levin, L. Fortova, etc.);

- the concept of spiritual and moral education (H. Berdyaev, V. Dodonov, A. Kislov, etc.);

- research on theoretical problems of training preventive teachers (N. Kuzmina, V. Slastenin, V. Shadrikov, N. Shchurkova, etc.);

- theory of prevention of deviant behavior of minors (Y. Gilinsky, N. Mansurov, S. Gavrilov, M. Alemaskin, D. Feldstein, etc.).

\section{RESEARCH METHODS / МЕTОДИ ДОСЛІДЖЕННЯ / МЕТОДЫ ИССЛЕДОВАНИЯ}

The following research methods were used during the research:

- theoretical analysis and composition. Scientific-pedagogical, psychological and methodological literature was studied and analyzed to study the research situation of the problem (D. Feldstein, «Features of the leading activities of adolescent children», R. Huseynzada, L. Allahverdiyeva «Family pedagogy», H. Sirota, V. Yaltonskiy «Drug addiction: prevention program for adolescents and youth»);

- pedagogical observation. In connection with the research, lessons, extracurricular activities were observed in Yevlakh city secondary schools No. 8 and Mingachevir city secondary schools No 1 and 4, their analysis was carried out, pedagogical experience was generalized; 
- pedagogical interviews were conducted with teachers of literature and history of secondary schools, deputy principals for educational work, class teachers, librarians, school psychologists, representatives of student organizations and school boys and girls;

- mathematical-statistical methods. The data obtained on the basis of survey and experimental methods were systematized and grouped, on this basis, generalizations were made, it was possible to determine the quantitative dependencies between the studied pedagogical events and processes.

\section{RESEARCH RESULTS / РЕЗУЛЬТАТИ ДОСЛІДЖЕННЯ / РЕЗУЛЬТАТЫ ИССЛЕДОВАНИЯ}

At the age of upper class there are some differences in meaning and values. Determining the right position in life depends on the choice of profession. Schoolchildren do not feel ready to make such choices yet. The values are more affected by the age. Friendship and love is the main problem of the mentioned age and the solution to this problem is very important. According to the degree of impact on the values, the type of educational institution in which the training is implemented is the second issue.

Physical and psychological changes occur during the age of upper class. Any social reactions to these changes are related upper class students. The destructive conflicts that arise during this period are directly linked to the inadequate and tactless approach of adults to them.

The main task of the educator and the teacher is to ensure the integration of new, positive and stable feelings of upper class students in their identity. Changes in physical appearance greatly affect teenagers' freedom. Dissatisfaction with new physical appearance, the attitude of the surrounding people to these changes can lead to deprivation and frustration symptoms and syndromes, negative conflicts, depression, behavioral deviations and even functional dysfunctions (neuroses, neurasthenia and psychopathy).

During this age, training is considered the main type of activity. However, unlike early adolescence (generally ages eleven to fourteen); the late adolescence years (ages eighteen to twenty-one) «The training activity acts as a form of general public - useful activity for their psychological role, protecting their meaning and relevance», wrote D. Feldstein [4].

Hence, beneficial activities are becoming the leading type of activity for the upper class students for its various forms such as training, labor, and publicorganizational forms.

At this age, there are no signs of new qualifications of intellectual 
development, but formal intellectual development processes which started at early adolescence years, are strengthened and improved. However, there is some specificity and it is associated with the personal development of the upper class student. The cognitive of teenagers is characterized more personal and emotional. L. Bojovic pointed out that intellectual activity is associated with the understanding of the student's self-awareness and the broadening of his outlook, gaining a special affective tinge [5]. This affective effort reveals the peculiarity of thinking in the last adolescence years.

It should be noted that the physical appearance of older schoolchildren is one of the main reasons for the conflict: there are some changes in their walking styles, tastes, physical appearance. Slow, free acts are transferred into severity and rudeness. The boys walk with their hands in their pockets and poor posture and speak as if they grit their teeth. Girls compare their hairstyle and clothing with others', they see in the street or on the cover of the magazines with jealousy, and express their dissatisfaction to their mothers in an emotional way. This also results in family conflicts and disagreements.

The relationships between upper-class students and their parents depend on their spiritual-emotional affinity. Mutual understanding in the family remains a key and important factor for older school children and in this context, the activity of the educator does not play any role.

The problems arising in interaction of adolescents with adults are also related to the fact that, teenagers protest against the protection and doubts and wants to be free on one hand, but on the other hand, when they face new challenges and experience stress and anxious, they expect help and support from elders. However they never admit it.

As a result of the development of an upper class student in society, the roles change; parents are substituted by referent groups consisting of peers. Replacement of the center of development from family to the referent groups leads to intra-family conflicts. However, the family remains a key social asset for the upper class student.

The referent society is crucial for the development of identity of olderschool age students during this period. At that time, the young person literally feels his / her individuality and freedom.

Understanding the characteristics of the growth will help the educator to work more efficiently.

Thus, we can note that the general characteristic of this age differs with the following aspects of behavior:

- with emotional changes; 
- with sudden change of mood;

- with high self-esteem;

- with sharp judgments;

- shyness and self - distrust.

Hence, during the period of growth, an upper class student solves a few specific issues related to the development of his personality: identification of physical appearance, improvement of shape of the body (sport), proper organization of leisure time, self-improvement, art, labor; understanding of sexual behaviors, acquisition of social competence; preparation for future profession, formation of responsible behavior, mastering the system of values and developing ethical consciousness, ability to survive destructive stresses, analysis of life, death, supreme forces.

Nowadays, schools try to solve aforementioned problems and they help upper - class students to overcome growth related issues. Ideally children's relationship with parents, educators, and the school in general should serve as an open, sincere and important objective.

In general, experts recommend directing the main attention on the improving of the quality of education and training of upbringing generation rather than preventive (prophylactic) activities [6]. In addition, to pay special attention to the activities directed to form sense of affection to school and community in children and adolescents. Thus, cooperation between school and police in the United States and Great Britain is highly popular [7]. Psychological, social, and medical assistance centers which serve deviant behavioral adolescents according to the residential areas in the UK are widespread. The practical advice is provided to the parents and teachers, to optimize the educational and training process at home and at school in these centers. Establishing centers directed to organize leisure time for preventive practice such as year-round and seasonal camps in Commonwealth of Independent States can be of a great importance. The main purpose of these centers is to provide initial assistance in choosing a future profession, improve qualifications, and improve the skills and knowledge to address vital issues.

In our opinion, theoretical model of the pedagogical prophylaxis of deviant behavior of upper class students may include the following aspects of the prophylactic work:

- pedagogical work with upper class students;

- theoretical and methodological training of educators;

- work with family. 


\section{Table}

Directions of preventive work

\begin{tabular}{|c|c|c|c|c|}
\hline \multirow{2}{*}{ № } & \multirow{2}{*}{ Areas of activity } & \multicolumn{3}{|c|}{ Aims } \\
\hline & & Teachers & Schoolchildren & Parents \\
\hline 1 & $\begin{array}{l}\text { Ensuring health and } \\
\text { promoting a healthy lifestyle }\end{array}$ & $\begin{array}{l}\text { 1. To promote a } \\
\text { healthy lifestyle. } \\
\text { - Ensure } \\
\text { strengthening control } \\
\text { over the quality of } \\
\text { medical care provided } \\
\text { to children. } \\
\text { - Involve students } \\
\text { in sports and health } \\
\text { activities to stimulate }\end{array}$ & $\begin{array}{l}\text { Striving for a healthy } \\
\text { lifestyle }\end{array}$ & $\begin{array}{l}\text { Creating the } \\
\text { conditions created } \\
\text { to ensure health } \\
\text { and implementing } \\
\text { the advice of } \\
\text { teachers and } \\
\text { doctors }\end{array}$ \\
\hline 2 & $\begin{array}{l}\text { Ensuring moral and } \\
\text { voluntary training and civic } \\
\text { maturity }\end{array}$ & $\begin{array}{l}\text { To help children } \\
\text { achieve the optimal } \\
\text { level of spiritual and } \\
\text { voluntary training. To } \\
\text { help the individual to } \\
\text { solve the most } \\
\text { difficult problems of } \\
\text { life independently } \\
\text { and to establish a } \\
\text { positive activity, to } \\
\text { achieve the final } \\
\text { result }\end{array}$ & $\begin{array}{l}\text { To form a positive } \\
\text { «ego-concept» }\end{array}$ & $\begin{array}{l}\text { To assist children } \\
\text { in mastering } \\
\text { universal moral } \\
\text { and legal norms of } \\
\text { behavior, to } \\
\text { provide systematic } \\
\text { control over the } \\
\text { behavior of } \\
\text { students }\end{array}$ \\
\hline 3 & $\begin{array}{l}\text { Ensuring a comfortable } \\
\text { learning environment }\end{array}$ & $\begin{array}{l}\text { 1. To form the } \\
\text { learning and } \\
\text { communication skills } \\
\text { of high school } \\
\text { students. Develop an } \\
\text { educational program } \\
\text { for the formation of } \\
\text { reflexive and } \\
\text { communicative } \\
\text { culture }\end{array}$ & $\begin{array}{l}\text { 1. Mastering the } \\
\text { culture of } \\
\text { communicative and } \\
\text { reflexive skills. } \\
2 \text {. Develop a } \\
\text { responsible attitude } \\
\text { to the results of their } \\
\text { actions and behavior }\end{array}$ & $\begin{array}{l}\text { 1. To ensure } \\
\text { constant } \\
\text { interaction with } \\
\text { the school. } \\
2 . \text { To form a } \\
\text { responsible } \\
\text { relationship with } \\
\text { other subjects of } \\
\text { education as a } \\
\text { result of education }\end{array}$ \\
\hline 4 & $\begin{array}{l}\text { Ensuring an adequate } \\
\text { management and control } \\
\text { system }\end{array}$ & $\begin{array}{l}\text { 1. To receive } \\
\text { operative information } \\
\text { on the results of the } \\
\text { pedagogical staff on } \\
\text { the implementation of } \\
\text { the program. } \\
2 . \text { To organize } \\
\text { constructive } \\
\text { cooperation between } \\
\text { the subjects of } \\
\text { education on } \\
\text { correction of activity }\end{array}$ & $\begin{array}{l}\text { Organization of self- } \\
\text { analysis, self-control } \\
\text { of activities and } \\
\text { behavior }\end{array}$ & $\begin{array}{l}\text { Participate in the } \\
\text { analysis of the } \\
\text { results of the work } \\
\text { on the } \\
\text { implementation of } \\
\text { the program }\end{array}$ \\
\hline
\end{tabular}

We have tried to emphasize the following methods of the process in the model of prophylaxis of deviant behavior of upper class students: informative 
(based on the legal norms of behavior, provision of necessary information); methods related to the development of behavioral habits (analysis of specific life situations that are related to behavioral infringements, through discussions and problem analysis, promoting knowledge expansion); positive - constructive method (organization and conduct of trainings aimed at increasing psychological stability, eliminating tension, reducing excitement, increasing confidence, etc.). We propose to use a variety of forms of work in the organization of prophylactic work: lectures, conversations, seminars, conferences, disputes, sociological survey, and demonstration of video materials.

The prevention of modern addictions is aimed at its causes. Factors that hinder the formation of the addictive behavior and the factors promoting its formation are found at the same level as the biopsychosocial system: personality, social environment (family, school, and peer group), social environment, and conditions [8].

The educational opportunities of the society are multifaceted. Can the school use these opportunities effectively on its own? Definitely can't use it. This fact has already been confirmed in school practice. According to SM Guliyev, the school can become a center of social education only if it is approached systematically and solved by the same criteria. As a result of the realization of this fact, various forms of his interaction with the family, labor collectives and the community have emerged and been established in the work experience of schoolchildren.

It is clear from SM Guliyev's research that when considering the issue from a historical point of view, we can distinguish three stages: in the first stage, the school organized its work mainly in the context of interaction with the family. This is essentially the oldest form of communication. This form of communication was used to one degree or another when the school was still established as an institution of social education. However, in the post-war years, especially in the context of urbanization, the social functions of the school expanded. It began to use in his work not only forms of interaction with the family, but also with labor collectives. In the third stage, a special pedagogical quartet is formed in the system of social education of schoolchildren. School, family, labor collectives and the public are the main tools of the pedagogical quartet. Each of them has its place, opportunities and functions in the social education of children. The pedagogical quartet is a unique system, and each of its components must be studied in terms of the functions of that system. The link in this system is the school [14].

Family, school, and peer groups should hinder the development of addicts. 
Family is one of the oldest and unique forms of relationship of people. The uniqueness and peculiarity of the family is great. Many people spend a great deal of their lives closely with each other over a long period of time measuring ten years [9]. This creates an active social interaction of the growing generation and its emotional life, and establishes the value-normative structure of its identity. Law Enforcement Agencies and school educators have been convinced that the problems of adolescence begin in the family. The terms «socially unsuccessful family», "family included in the risk group» and so forth appeared. School is considered to be the second social institution that affects the socialization and development of the upper class student after family. This social institution not only develop the student's intellect and gives him/her any knowledge, but also shapes his behavioral model, values system, and interactions with the surrounding world. In addition to education, school offers children «educational space» of life. At school, children have the opportunity to communicate with other people, to build friendships with them, or to cut off these relationships, to find a place in the peers' group and so on. Especially educators can help children to develop their social skills. They establish foundation of the knowledge. Educators should focus primarily on the protection of healthy offspring, prevention of deviant behavior of upper class students. Optimal forms of training and education should be found for older school age students, which will enable to form important social aspects [10].

According to our model, the preparation of preventive work with educators on the prevention of deviant behavior of upper class students is organized in the following forms: pedagogical councils, round tables, practical seminars, and scientific-practical conferences, lectures of specialists, methodological associations, and psycho-pedagogical trainings.

In the upper classes, some of the students show great interest and love for the subject taught by the teacher's personality and reputation. Sometimes they choose professions and qualifications on these subjects. However, it is possible to find the opposite cases. Sometimes the teacher's rude attitudes towards students, his/her neglect to his/her profession, his/her disrespect to the students' personality, the mistreatment of their dignity, honor, and self-respect, his/her indiscriminate punishment, and so on, erase interest of the students to the subject of that teacher, students start to hate his/her subject. Therefore, the teacher should not forget that normal communication with his students will lead to solutions of many problems in the pedagogical process.

Among the good qualities that students value in their teachers, the most important are their sincerity, kindness, affection for his/her students, careful 
approach to his/her students, and good teaching methods. All this shows that one of the key issues for a teacher to gain love from his/her students, his/her success as a tutor/educator is his/her proper pedagogical attitude to students, sincere, friendly communication with them, and mutual cooperation [11].

Taking into account the specificity of communication with upper class students and their psychological features, the educator should have a number of key features: tact, sensitivity and cultural approaches; behavioral agility; emotional restraint; communication; ability to create psychological comfort; to respect the opinion of an upper class student; to the same extent as professional use of the same forms of verbal and non-verbal communication; to love and respect people, to understand and accept them as they are [12].

As a result of our researches, we have come to the conclusion that we have come to the conclusion that educators are highly responsible for the primary prevention of deviant behavior of upper class students. However a teacher's duties should not limited to have a direct educational impact on the students; the teacher must rely on the relevant potential of the parents and set out his / her work in a certain line.

Preventive work with family and parents is one of the next trends of our model. They have special potential for the prevention of deviant behavior. First of all, let's note that parents have great experiences. As representatives of different professions, parents have a clear vision of how harmful habits affect their labor productivity. Parent involvement in preventive activities is of paramount importance for upper class students.

Work with parents in this direction is carried out in the following directions:

- to provide information to parents about relevant programs;

- performances by physicians and psychologists at parent meetings;

- conducting individual work with parents of pupils exposed to certain addictions [12]

A. Makeyeva notes the general and special forms of work with parents [13]. The general work includes the following forms: holding conversations, reading lectures by professionals, consultations, organizing seminars with parents on family problems, upbringing, addictions; the involvement of parents in assisting other families in need of social support, and so on.

The role of other professionals in the work with parents, educators, and upper class students is also of great importance.

While the school psychologist carries out prophylactic work, at the same time the teacher promotes knowledge on pedagogical psychology among 
students. The teacher sets out various seminars, meetings, and leads them.

The psychologist also:

- carries out pedagogical and psychological conversations with teachers and students, and encourage them;

- organizes psychology-based courses and guides them;

- prepares a list of factors that adversely affect the behavior of an upper class student for parents and teachers;

- takes precautionary measures to prevent any difficulties in the education of a child and an adolescent;

- strives to create a healthy, moral, psychological environment for the education of upper class students in the field of education;

- sends upper class students and their parents to high-level specialized professionals who can help them.

The school psychologist can use the following methods and forms of work for the prevention of deviant behavior of senior pupils: training (personal behavior), cognitive therapy, discussions, lectures, mental attack, role-playing, group work, individual and group psychotherapy, psychogymeatics.

In the context of the school's relationship with public organizations, the activities of police child room workers are extremely selective. As N. Kazimov and A. Hashimov noted, they «carry out important work to prevent pedagogical negligence and violation of laws».

As a rule, school strives to address the problem of «challenging» children and, first of all, to influence children and adolescents through families, and families to raise the family's educational opportunities.

What should the content and the system of the interaction of the school with the police child's room be? Although this question was answered on the basis of legal principles, they were not socially-pedagogically explained.

The police child room inspector is on the one hand an administrative officer. He comes to school as a police officer and works as an administrative body officer with the relevant authorities. On the other hand, the police child room inspector is first of all a tutor. His pedagogical characteristics as a tutor have almost not been studied yet in Azerbaijan pedagogy. Police child room inspector plays a crucial role in the legal education of upper class students [14].

\section{CONCLUSIONS AND PROSPECTS FOR FURTHER RESEARCH / ВИСНОВКИ ТА ПЕРСПЕКТИВИ ПОДАЛЬШИХ ДОСЛІДЖЕНЬ / ВЫВОДЫ И ПЕРСПЕКТИВЫ ДАЛЬНЕЙШИХ ИССЛЕДОВАНИЙ}

By analyzing various sources, we have come to the conclusion that the 
typical psychological and pedagogical characteristics of the upper class student can be summarized as follows:

- physical features: they are fully developed physically, so they pay great attention to their health;

- emotional features: they are already full of affection towards all family members; they can be more attentive to the needs of others, than themselves;

- social features: they are eager to establish serious relationships with the opposite sex (love), and even their own sex (friendship); some meetings become commonplace in their lives; personal relationships come to the forefront, loyalty and devotion in these relationships become main indicator;

- intellectual features: try to make more serious and logical decisions; they already realize that the decision taken today can have an impact on what will happen tomorrow; strengthen their control on their behavior; they try to solve problems that arise during conflicts with their parents; They start to think about their profession and generally about their future;

- moral characteristics: try to test moral and ethical values; they behave very well with the people around them and they start to care about other peoples' opinions about them; life after death makes them think too much; there are numerous questions about their personal spiritual lives and, therefore, in most cases, they hesitate.

Prospects for further research. As a result of our analysis, we have come to this conclusion that nowadays researches on deviant behavioral problems have tried to cover the problem by working on a complex system of preventive impact, involving different profile professionals and investigating the facts system. Prevention of deviant behavior of teenagers requires the development and implementation of preventive measures. It also provides a basis for preventive measures in the legal, social, medical, psychological and pedagogical levels.

Thus, we believe that the directions of joint work of family, school and community on the pedagogical prophylaxis of deviant behavior of upper class students should create a basis for a healthy generation to grow and really influence the selection of goals in future lives of the upper class students.

\section{REFERENCES / СПИСОК ВИКОРИСТАНИХ ДЖЕРЕЛ / СПИСОК ЛИТЕРАТУРЫ (TRANSLATED AND TRANSLITERATED)}

[1] Children in Conflict with the Law: Child Protection Information Sheet 2015. The United Nations Children's Fund (UNICEF). May, 2006. [Online]. Available: http://www.unicef.org/protection/files/Conflict with the Law.pdf 
[2] Л. И.Божович, Личность и ее формирование в детском возрасте. Санкт-Петербург, Россия: Питер, 2008, 400 с.

[3] В. Г. Бочарова, Педагогика социальной работы. Москва, Россия: SvRАргус, 1994, 207 с.

[4] Д. И. Фельдштейн, Особенности ведущей деятельности детей подросткового возраста: хрестоматия по детской психологии: от младенца до подростка; Г. В. Бурменской, Ре. Москва, Рссия: МПСИ, 2004, 412 c.

[5] Л. И. Божович, Личность и ее развитие в детском возрасте. Москва, Россия, 1968, 278 с.

[6] I. Kandugasheva, «Methods of Preventing Deviant Behavior among Adolescents in Secondary School», Scientific research and development. Socio-humanitarian research and technology, 2015, № 4(3), p. 56-58. [Online].

Available: www.researchgate.net/publication/284710281 Methods of $\mathrm{Pr}$ eventing Deviant Behav-ior Among Adolescents in Secondary School

[7] S. E. Danforth, T. J. Smith, Engaging Troubling Students: A Constructivist Approach. Thousand Oaks, CA: Corwin Press, 2005, 336 p.

[8] Е. Т. Соколова, Самосознание и самооценка при аномалиях личности: учеб. пособие. Москва, Россия: МГУ, 1989, 210 с.

[9] R. L. Hüseynzadə, L. Z. Allahverdiyeva, Ailə pedaqogikası. Bakı, Azərbaycan: ADPU-nun mətbəəsi, 2016, 339 s.

[10] М. В. Бредихина, «Педогагическая профилактика игровых зависимостей у поростков в общеобразовательном учреждении»: дис. канд. наук. Владимир, 2007, 251 с.

[11] M. İ. İlyasov, Müallimin pedaqoji ustalı̆̆ı: Dars vəsaiti. Bakl, Azərbaycan: Elm və təhsil, 2013, 216 s.

[12] Н. А.Сирота, В. М. Ялтонский, О. В.Зыков [и др.], Наркомания: программа профилактики среди подростков и молодежи. Москва, Россия: Сб. НИИ наркологии МЗ РФ, 1988, 81 с.

[13] А. Г. Макеева, И. А. Лысенко, Долго ли до беды? Педагогическая профилактика детского наркотизма. Москва, Россия: Линка-Пресс, 2000, 156 c.

[14] H. Ә. Әlizadə, R. M. Mahmudova, Sosial pedaqogika. Bakı, Azərbaycan: Bakı Universiteti, 2013, $368 \mathrm{~s}$. 


\title{
МОЖЛИВОСТІ ПЕДАГОГІЧНОГО КВАРТЕТУ У ПРОФІЛАКТИЦІ ДЕВІАНТНОЇ ПОВЕДІНКИ З УРАХУВАННЯМ ПЕДАГОГІЧНИХ ТА ПСИХОЛОГІЧНИХ ОСОБЛИВОСТЕЙ СТАРШОКЛАСНИКІВ
}

\author{
Джаббарова Кёнуль Гідаят гизи, \\ ст. викладач Мінгечевірского Державного Університету; \\ дисертант Інституту Освіти Азербайджанської Республіки. \\ Мінгечевір, Азербайджан. \\ ORCID iD: https://orcid.org/0000-0003-2137-2412 \\ kenulcabbarova@gmail.com
}

Анотація. Виникнення соціально-педагогічних чинників девіантної поведінки у старшокласників спирається на рівень взаємної роботи сімейного, шкільного і соціального виховання. Основа морального виховання старшокласників закладається в сім'ї, тому безвідповідальне ставлення до своєї долі, наявність двоякою моралі в їх вихованні і те, що їх батьки вживають алкоголь і наркотики, призводять до дисгармонії в родині і підштовхує його зробити перший крок на шляху до девіантної поведінки. Хоча i старшокласник хоче адаптуватися до вимог суспільства, але він не може цього зробити, тому що не знає, як належним чином зіграти свою соціальну роль і не знає про способи соціальної адаптації. У статті проаналізовані способи організації спільної роботи сім'ї, школи та суспільства щодо профілактики девіантної поведінки старшокласників, представлена теоретична модель педагогічної профілактики девіантної поведінки старшокласників, вказані напрямки профілактичної роботи. Школа, сім'я, трудові колективи і суспільство представлені як сторони педагогічного квартету. Зазначені в моделі особливості, методи і тд., Аналізуються в усіх напрямах. Основна мета суспільства і системи шкільної освіти в наш час - забезпечити цивільне участь підлітків, особливо старшокласників, в житті мінливого суспільства. Однак відсутність реальних програм, спеціально навчених вчителів, в області девіантної поведінки i погано розвинена мережа методичної підтримки призводять до затримки цього процесу. У статті також $є$ кілька пропозицій щодо цих питань. У результаті аналізу зроблено висновок, що профілактика девіантної поведінки підлітків вимагає превентивної розробки і реалізації спеціальних профілактичних заходів. Крім того, маючи профілактичний характер, він створює основу для проведення системи профілактичних заходів на 
правовому, соціальному, медичному, психологічному і педагогічному рівнях.

Ключові слова: старшокласник; контроль; сім'я; школа; девіантна поведінка; соціальне середовище; педагогічна профілактика.

\title{
ВОЗМОЖНОСТИ ПЕДАГОГИЧЕСКОГО КВАРТЕТА В ПРОФИЛАКТИКЕ ДЕВИАНТНОГО ПОВЕДЕНИЯ С УЧЕТОМ ПЕДАГОГИЧЕСКИХ И ПСИХОЛОГИЧЕСКИХ ОСОБЕННОСТЕЙ СТАРШЕКЛАССНИКОВ
}

\author{
Джаббарова Кёнуль Гидаят гызы, \\ ст. преподаватель Мингечевирского Государственного Университета; \\ диссертант Института образования Азербайджанской Республики. \\ Мингечевир, Азербайджан. \\ ORCID iD: https://orcid.org/0000-0003-2137-2412 \\ kenulcabbarova@gmail.com
}

Аннотация. Возникновение социально-педагогических факторов девиантного поведения у старшеклассников опирается на уровень взаимной работы семейного, школьного и социального воспитания. Основа нравственного воспитания старшеклассников закладывается в семье, поэтому безответственное отношение к своей судьбе, наличие двоякой морали в их воспитании и то, что их родители употребляют алкоголь и наркотики, приводят к дисгармонии в семье и подталкивает его сделать первый шаг на пути к девиантному поведению. Хотя и старшеклассник хочет адаптироваться к требованиям общества, но он не может этого сделать, потому что не знает, как должным образом сыграть свою социальную роль и не знает о способах социальной адаптации. В статье проанализированы способы организации совместной работы семьи, школы и общества по профилактике девиантного поведения старшеклассников, представлена теоретическая модель педагогической профилактики девиантного поведения старшеклассников, указаны направления профилактической работы. Школа, семья, трудовые коллективы и общество представлены как стороны педагогического квартета. Указанные в модели особенности, методы и тд., анализируются по всем направлениям. Основная цель общества и системы школьного образования в наше время - обеспечить цивильное участие подростков, особенно старшеклассников, в жизни меняющегося общества. Однако отсутствие реальных программ, специально обученных учителей, в области девиантного поведения и плохо 
развитая сеть методической поддержки приводят к задержке этого процесса. В статье также есть несколько предложений по этим вопросам. В результате анализа сделан вывод, что профилактика девиантного поведения подростков требует превентивной разработки и реализации специальных профилактических мероприятий. Кроме того, имея профилактический характер, он создает основу для проведения системы профилактических мероприятий на правовом, социальном, медицинском, психологическом и педагогическом уровнях.

Ключевые слова: старшеклассник; контроль; семья; школа; девиантное поведение; социальная среда; педагогическая профілактика.

\section{REFERENCES (TRANSLATED AND TRANSLITERATED)}

[1] Children in Conflict with the Law: Child Protection Information Sheet 2015. The United Nations Children's Fund (UNICEF). May, 2006. [Online]. Available: http://www.unicef.org/protection/files/Conflict with the Law.pdf

[2] L. I. Bozhovich, Lichnost' i ee formirovanie v detskom vozraste. SanktPeterburg, Rossiya: Piter, 2008, 400 s.

[3] V. G. Bocharova, Pedagogika social'noj raboty. Moskva, Rossiya: SvR-Argus, 1994, $207 \mathrm{~s}$.

[4] D. I. Fel'dshtejn, Osobennosti vedushchej deyatel'nosti detej podrostkovogo vozrasta: hrestomatiya po detskoj psihologii: ot mladenca do podrostka; G. V. Burmenskoj, Re. Moskva, Rssiya: MPSI, 2004, $412 \mathrm{~s}$.

[5] L. I. Bozhovich, Lichnost' i ee razvitie v detskom vozraste. Moskva, Rossiya, 1968, $278 \mathrm{~s}$.

[6] I. Kandugasheva, «Methods of Preventing Deviant Behavior among Adolescents in Secondary School», Scientific research and development. Socio-humanitarian research and technology, 2015, № 4(3), p. 56-58. [Online].

Available: www.researchgate.net/publication/284710281 Methods of $\mathrm{Pr}$ eventing Deviant Behav-ior Among Adolescents in Secondary School

[7] S. E. Danforth, T. J. Smith, Engaging Troubling Students: A Constructivist Ap-proach. Thousand Oaks, CA: Corwin Press, 2005, 336 p.

[8] E. T. Sokolova, Samosoznanie i samoocenka pri anomaliyah lichnosti: ucheb. posobie. Moskva, Rossiya: MGU, 1989, 210 s.

[9] R. L. Huseynzade, L. Z. Allahverdiyeva, Family pedagogy. Baku, Azerbaijan: ADPU printing house, 2016, 339 p. 
[10] M. V. Bredihina, «Pedogagicheskaya profilaktika igrovyh zavisimostej u porostkov $\mathrm{v}$ obshcheobrazovatel'nom uchrezhdenii»: dis. kand. nauk. Vladimir, 2007, $251 \mathrm{~s}$.

[11] M. İ. Ilyasov, Teacher's pedagogical skills: Textbook. Baku, Azerbaijan: Science and education, 2013, $216 \mathrm{p}$.

[12] N. A. Sirota, V. M. YAltonskij, O. V. Zykov [i dr.], Narkomaniya: programma profilaktiki sredi podrostkov i molodezhi. Moskva, Rossiya: Sb. NII narkologii MZ RF, 1988, $81 \mathrm{c}$.

[13] A. G. Makeeva, I. A. Lysenko, Dolgo li do bedy? Pedagogicheskaya profilaktika detskogo narkotizma. Moskva, Rossiya: Linka-Press, 2000, $156 \mathrm{~s}$.

[14] H. A. Alizada, R. M. Mahmudova, Social pedagogy. Baku, Azerbaijan: Baku University, 2013, 368 p. 